\title{
INTUBATION STUDIES OF THE HUMAN SMALL INTESTINE. XXV. THE ABSORPTION OF GALACTOSE FROM THE INTESTINE OF NORMAL INDIVIDUALS AND THYROTOXIC PATIENTS
}

\author{
By VINCE MOSELEY AND FRANCIS W. CHORNOCK \\ (From the Gastro-Intestinal Section, Kinsey-Thomas Foundation, of the Medical Clinic, \\ Hospital of the University of Pennsylvania, Philadelphia)
}

(Received for publication December 10, 1945)

The concentration of galactose in the blood stream at determined intervals after its ingestion has been proposed as a clinical test of intestinal absorption (1). It is said not only to indicate the rate at which galactose is absorbed from the intestine, but also to be a means of measuring the ability with which and the rate at which the intestinal mucosa absorbs various substances by the mechanism of phosphorylation (1 to 4). Some workers, finding by this procedure that the thyrotoxic patient shows a higher galactose curve than does the normal subject, have attributed this result to a specific accelerating action on intestinal absorption by the thyroid hormone (2 to 5 ).

The blood concentration of a substance following its ingestion, however, is not dependent solely on the capacity of the intestinal mucosa to absorb it. First of all, and most important, it is necessary to know whether or not, and to what extent, the material reaches the absorbing surface, and so is available for absorption. The hexoses are absorbed chiefly from the duodenum and jejunum (6 to 9), and from the stomach only when in hypertonic solution $(10,9)$. Consequently, alterations in gastric and intestinal motility, whether due to organic or functional disturbances, may profoundly affect the availability of the ingested galactose in the absorbing area $(6,29 \mathrm{~b}, 29 \mathrm{c})$. In spite of the experimental evidence that glucose and galactose orally administered are absorbed at a constant rate and independent of their concentration $(11,12,8)$, this holds true only within certain limits $(13,6)$. When widely varying concentrations of a sugar are introduced directly into the intestine the absorption rate is proportional to the concentration $(15,29 \mathrm{~d}, 31,32,36)$.

Secondly, it has been demonstrated in animals that irrespective of the actual rate of hexose absorption, the concentration in the blood is chiefly dependent on metabolic factors $(11,12)$. In this respect the liver is the principal, though not the sole, organ involved $(14,15,19 \mathrm{~b}, 24,35)$. Hepatic dysfunction especially has been held responsible by some authors for the hypergalactemia found after the ingestion of that sugar in the thyrotoxic patient (29a). Furthermore, in such a condition, as well as in cases with various nutritional, endocrine, and urinary tract disturbances, the renal output of the sugar is often altered (16 to $24,14,15$ ). Thus the rate of its excretion constitutes a third factor that influences the concentration of galactose in the blood $(24,29 \mathrm{e})$.

Finally, it has been claimed, as we shall show, that the blood concentration of galactose is in some way affected by the coincident concentration of glucose $(15,16,20,21,25)$.

In an attempt to obviate some of these disturbing factors, we have employed the absorption technique devised by Nicholson and Chornock (26), which makes possible over a fixed period of time the presence of a known quantity of the galactose in a predetermined area of the intestinal tract. Thus it measures accurately the availability of the galactose for absorption and the actual quantity absorbed, and so eliminates the chief factors that previously, for the human subject, had not been controlled. The other factors, metabolic disturbances and excretion through the kidneys, have been controlled insofar as possible by the selection of the subjects for the experiments.

\section{SUBJECTS AND METHODS}

For this study, 6 normal persons and 5 patients with thyrotoxicosis were employed. The normals were paid subjects found to be in good health by history, physical examination, and clinical laboratory studies. Radiological examinations of the gastro-intestinal tract and the basal metabolic rates were within normal limits. The hyperthyroid subjects exhibited clear-cut clinical pictures of thyrotoxicosis, and were patients from the medical wards awaiting thyroid surgery. 
The details of the technique developed by Nicholson and Chornock need not be repeated. It involves the injection of the test solution into the mid-duodenum through one lumen of the Miller-Abbott tube (27) and the removal of the residue from the jejuno-ileal area, $90 \mathrm{~cm}$. lower in the tract, through the other lumen.

The subjects fasted 12 hours (overnight) and on the morning of the test day, after getting the apparatus into its proper position, which usually required 2 to 3 hours, the absorption study was undertaken. The absorption period varied from 30 to 90 minutes, and the exact procedure was as follows: A 10 per cent solution of galactose was allowed to drip into the mid-duodenum via the first lumen at a rate of $10 \mathrm{ml}$. per minute. It was introduced by means of a flask with a Murphy drip attachment at a hydrostatic pressure of $75 \mathrm{~cm}$. The rate of drip was regulated by means of a Hoffman clamp. This concentration of galactose and the rate of its administration were selected after preliminary experiments indicated that they gave the most consistent results.

As soon as the galactose began to flow into the duodenum, aspiration of the succus from the jejunum was begun. All of the material aspirated during the experimental period was collected in flask No. 1 and subsequently analyzed quantitatively for its galactose content. By subtracting this unabsorbed quantity, plus the quantities obtained in flasks $2,3,4$ and 5 (the details of collection of which are outlined below), from the amount administered, a calculation of the amount absorbed was derived.

After administering the desired quantity of galactose, the absorption period was abruptly terminated by discontinuing the galactose drip, removing flask No. 1 and injecting $30 \mathrm{ml}$. of a 33 per cent solution of magnesium sulfate into the duodenum. In each experiment, in order to check on the abruptness with which the absorbing period was ended, a 30-minute period of washing the bowel with tap water was carried out. Aspiration was continued using flasks Nos. 2, 3 and 4 for the collection at 10-, 20- and 30-minute periods. Each of the specimens obtained during this wash period was analyzed for galactose. The tap water wash was performed in the same manner as the galactose was administered.

As can be seen by reference to Table I, except in specimen No. 2, which immediately followed the magnesium sulfate injection, only traces of galactose were present after the experimental period, thus indicating that the peristaltic rush induced by the magnesium sulfate solution was highly effective in abruptly terminating the absorption period. The intensity of this peristaltic rush, and the completeness with which it cleared the intestinal lumen, were confirmed in a few experiments by adding vital red in known concentration to the magnesium sulfate solution and determining its time of appearance; this was from 1 to 3 minutes. Furthermore, it was demonstrated that most of the dye and the sugar contained in specimen

TABLE I

The absorption of galactose from a 90-cm. segment of the human duodeno-jejunum during its administration at a fuxed rate into the duodenum in normal and thyrotoxic individuals

\begin{tabular}{|c|c|c|c|c|c|c|c|c|c|}
\hline \multirow{3}{*}{ Subject } & \multirow{3}{*}{$\begin{array}{c}\text { Galactose } \\
\text { adminis- } \\
\text { tered in } \\
10 \text { per cent } \\
\text { solution }\end{array}$} & \multirow{3}{*}{$\begin{array}{l}\text { Experi- } \\
\text { mental } \\
\text { period }\end{array}$} & \multicolumn{5}{|c|}{ Galactose recovery } & \multirow{3}{*}{$\begin{array}{l}\text { Galactose } \\
\text { absorbed }\end{array}$} & \multirow{3}{*}{ Remarks } \\
\hline & & & \multirow{2}{*}{$\begin{array}{c}\text { Absorption } \\
\text { period. } \\
\text { Spec. } 1\end{array}$} & \multicolumn{4}{|c|}{ Following $\mathrm{MgSO}_{4}$ injection } & & \\
\hline & & & & Spec. 2 & Spec. 3 & Spec. 4 & Spec. 5 & & \\
\hline H.M. & $\begin{array}{c}\text { grams } \\
30.0\end{array}$ & $\begin{array}{c}\min . \\
30\end{array}$ & $\begin{array}{r}\text { grams } \\
9.20\end{array}$ & $\begin{array}{c}\text { grams } \\
0.98\end{array}$ & $\begin{array}{l}\text { grams } \\
0.11\end{array}$ & $\begin{array}{l}\text { grams } \\
0.02\end{array}$ & $\begin{array}{l}\text { grams } \\
0.00\end{array}$ & $\begin{array}{c}\text { grams } \\
19.7\end{array}$ & Control subject \\
\hline G.C. & 30.0 & 30 & 1.60 & 2.82 & 0.00 & 0.00 & 0.00 & 25.6 & Control subject \\
\hline M.B. & 30.0 & 30 & 6.89 & 0.82 & 0.01 & 0.00 & 0.00 & 22.3 & Control subject \\
\hline C.B. & 30.0 & 30 & 8.53 & 3.64 & 0.09 & 0.00 & 0.02 & 17.7 & Control subject \\
\hline D.N. & 30.0 & 30 & 10.23 & 4.10 & 0.09 & 0.00 & 0.00 & 15.6 & Control subject \\
\hline G.C. & 60.0 & 60 & 22.40 & 2.00 & 0.20 & 0.02 & 0.00 & 35.4 & Control subject \\
\hline M.B. & 60.5 & 60 & 9.61 & 0.72 & 0.21 & 0.00 & 0.06 & 50.0 & Control subject \\
\hline H.M. & 55.5 & 60 & 22.80 & 2.41 & 0.05 & 0.01 & 0.00 & 30.2 & Control subject \\
\hline C.B. & 91.0 & 90 & 29.47 & 3.28 & 1.09 & 1.02 & 0.00 & 56.2 & Control subject \\
\hline W.J.A. & 30.0 & 30 & 11.18 & 0.79 & 0.00 & 0.00 & 0.10 & 17.9 & Thyrotoxic patient \\
\hline H.A. & 30.0 & 30 & 5.60 & 4.90 & 0.00 & 0.00 & 0.00 & 19.5 & Thyrotoxic patient \\
\hline M.T. & 30.0 & 30 & 8.28 & 6.13 & 1.53 & 0.62 & 0.00 & 13.4 & Thyrotoxic patient \\
\hline D.W. & 30.0 & 30 & 2.82 & 6.53 & 0.86 & 0.58 & 0.01 & 19.2 & Thyrotoxic patient \\
\hline
\end{tabular}


TABLE II

The absorption of galactose from the duodeno-jejunum per square meter of body surface per $\frac{1}{2}$ hour in normal and thyrotoxic individuals

\begin{tabular}{|c|c|c|c|c|c|c|c|c|c|}
\hline \multicolumn{6}{|c|}{ Subject } & \multicolumn{4}{|c|}{ Galactose } \\
\hline Initials & Sex/Age & Height & Weight & $\begin{array}{l}\text { Body sur- } \\
\text { face area }\end{array}$ & $\begin{array}{l}\text { Basal meta- } \\
\text { bolic rate }\end{array}$ & $\begin{array}{l}\text { Adminis- } \\
\text { tered by } \\
\text { tube }\end{array}$ & $\begin{array}{l}\text { Experi- } \\
\text { mental } \\
\text { period }\end{array}$ & $\begin{array}{c}\text { Total } \\
\text { absorbed }\end{array}$ & $\begin{array}{l}\text { Amount ab- } \\
\text { sorbed per } \\
\text { sq. meter } \\
\text { per } 30 \mathrm{~min} .\end{array}$ \\
\hline H.M. & M/29 & $\begin{array}{l}\text { inches } \\
65\end{array}$ & $\begin{array}{l}\text { lbs. } \\
148\end{array}$ & $\begin{array}{c}\text { sq. meters } \\
1.74\end{array}$ & $\begin{array}{c}\text { per cent } \\
-18\end{array}$ & $\begin{array}{l}\text { grams } \\
30 \\
60 \\
55.5\end{array}$ & $\begin{array}{c}\min . \\
30 \\
60 \\
60\end{array}$ & $\begin{array}{c}\text { grams } \\
19.7 \\
35.8 \\
30.2\end{array}$ & $\begin{array}{r}\text { grams } \\
11.4 \\
10.2 \\
8.8\end{array}$ \\
\hline G.C. & $M / 31$ & 72 & 201 & 2.12 & -8 & $\begin{array}{l}30 \\
30 \\
60\end{array}$ & $\begin{array}{l}30 \\
30 \\
60\end{array}$ & $\begin{array}{l}25.6 \\
25.5 \\
35.4\end{array}$ & $\begin{array}{r}12.0 \\
12.1 \\
8.8\end{array}$ \\
\hline M.B. & $F / 38$ & $61 \frac{1}{2}$ & 133 & 1.59 & -3 & $\begin{array}{l}30 \\
60.5 \\
59.7 \\
30 \\
30\end{array}$ & $\begin{array}{l}30 \\
60 \\
60 \\
30 \\
30\end{array}$ & $\begin{array}{l}22.3 \\
50.0 \\
41.9 \\
24.7 \\
25.0\end{array}$ & $\begin{array}{l}14.2 \\
15.6 \\
13.0 \\
15.5 \\
15.7\end{array}$ \\
\hline C.B. & $F / 60$ & $61 \frac{1}{2}$ & $102 \frac{1}{2}$ & 1.42 & +3 & $\begin{array}{l}30 \\
30 \\
52.5 \\
60 \\
91\end{array}$ & $\begin{array}{l}30 \\
30 \\
60 \\
60 \\
90\end{array}$ & $\begin{array}{l}17.7 \\
18.7 \\
29.1 \\
25.5 \\
56.2\end{array}$ & $\begin{array}{r}12.2 \\
13.2 \\
10.0 \\
9.0 \\
13.2\end{array}$ \\
\hline D.N. & $F / 23$ & 66 & 126 & 1.62 & & 30 & 30 & 15.6 & 9.6 \\
\hline S.B. & $\mathbf{F} / 30$ & 66 & 110 & 1.53 & & 61 & 60 & 44.4 & 14.5 \\
\hline H.A.* & $F / 56$ & 60 & $125 \frac{1}{2}$ & 1.52 & +42 & 30 & 30 & 19.5 & 12.8 \\
\hline W.J.A.* & $\mathrm{M} / 51$ & $65 \frac{3}{4}$ & 110 & 1.53 & +30 & 30 & 30 & 17.9 & 11.8 \\
\hline M.T.* & F/49 & 67 & 106 & 1.53 & +30 & 30 & 30 & 13.4 & 8.7 \\
\hline D.W.* & $F / 47$ & $61 \frac{1}{2}$ & 108 & 1.45 & +18 & 30 & 30 & 19.2 & 13.2 \\
\hline L.M.* & $F / 30$ & 72 & $137 \frac{1}{2}$ & 1.81 & +38 & 30 & 30 & 26.1 & 14.4 \\
\hline
\end{tabular}

* Thyrotoxic patient.

No. 2 appeared within the first 5 minutes of the 10 -minute period of aspiration.

As a further check in every experiment, a fifth specimen (No. 5) was collected and analyzed. This consisted of the material that could be aspirated from the duodenum and stomach during the time the tube was being withdrawn. When any considerable amount of galactose was detected in this specimen, the experiment was discarded.

The absorption studies were conducted in the beginning over periods of 30,60 and 90 minutes. As these revealed the rate of absorption to be fairly constant, a 30-minute period was chosen as satisfactory for the experiments comparing the results in normal and thyrotoxic patients (Tables I and II).

In addition to comparing the rate of galactose absorption in normal and hyperthyroid patients by this method, blood specimens were drawn at 1/2-, 1- and 2-hour periods after beginning the galactose administration, to determine the concentration of galactose in the blood stream (Tables
III and IV). Thus a comparison of the blood galactose values of normal and of hyperthyroid individuals was accomplished simultaneously with the measurement of the amount of galactose absorbed from the intestine.

In a small group of experiments, a solution of glucose was administered $1 / 2$ hour prior to the administration of the galactose solution, using the same technique of administration as was employed for the galactose. This modification of the experiment was employed in order to determine what effect this previous administration of glucose would have on the absorption of the galactose from the intestine, and on the concentration of galactose in the blood (Table V).

In every instance the chemical determinations on the blood and succus entericus specimens were conducted promptly after their collection.

\section{Determination of blood galactose.}

The blood specimens were collected in thymolfluoride tubes. Haden's methods for protein precipitation and for 
TABLE III

\begin{tabular}{|c|c|c|c|c|c|c|c|}
\hline \multirow{2}{*}{ Subject } & \multirow{2}{*}{$\begin{array}{l}\text { Galac- } \\
\text { tose } \\
\text { ad- } \\
\text { minis- } \\
\text { tered }\end{array}$} & \multirow{2}{*}{$\begin{array}{c}\text { Ex- } \\
\text { peri- } \\
\text { mental } \\
\text { period }\end{array}$} & \multirow{2}{*}{$\begin{array}{l}\text { Galac- } \\
\text { tose } \\
\text { ab- } \\
\text { sorbed }\end{array}$} & \multirow{2}{*}{$\begin{array}{c}\text { Galac- } \\
\text { tose ab } \\
\text { sorbed } \\
\text { per sq. } \\
\text { meter } \\
\text { per } \\
\text { hr. }\end{array}$} & \multicolumn{3}{|c|}{$\begin{array}{l}\text { Blood galactose } \\
\text { concentration }\end{array}$} \\
\hline & & & & & thour & 1 hour & 2 hours \\
\hline G.C. & $\begin{array}{l}\text { grams } \\
30\end{array}$ & $\begin{array}{c}\text { min. } \\
30\end{array}$ & $\begin{array}{l}\text { grams } \\
25.5\end{array}$ & $\begin{array}{c}\text { grams } \\
12.1\end{array}$ & $\begin{array}{c}\underset{\text { per }}{\operatorname{mgm}} \\
\text { cent } \\
88\end{array}$ & $\begin{array}{c}\underset{\text { per }}{\text { perm. }} \\
\text { cent } \\
69\end{array}$ & $\begin{array}{c}\text { mgm. } \\
\text { per } \\
\text { cent }\end{array}$ \\
\hline M.B. & \begin{tabular}{|l|}
59.7 \\
60 \\
30
\end{tabular} & $\begin{array}{l}60 \\
60 \\
30\end{array}$ & $\begin{array}{l}41.9 \\
50.0 \\
24.6\end{array}$ & $\begin{array}{l}13.0 \\
15.6 \\
15.5\end{array}$ & $\begin{array}{l}52 \\
52 \\
58\end{array}$ & $\begin{array}{l}67 \\
66 \\
22\end{array}$ & 9 \\
\hline H.M. & 60 & 60 & 35.8 & 10.2 & & 47 & 11 \\
\hline C.B. & $\begin{array}{l}60 \\
52 \\
30 \\
22.5^{*} \\
45.0 \dagger\end{array}$ & $\begin{array}{l}60 \\
60 \\
30 \\
30 \\
30\end{array}$ & $\begin{array}{l}25.5 \\
29.1 \\
18.7 \\
21.5 \\
29 .\end{array}$ & $\begin{array}{r}9.0 \\
10.0 \\
13.2 \\
15.0 \\
20.0\end{array}$ & $\begin{array}{l}37 \\
42 \\
42 \\
55\end{array}$ & $\begin{array}{l}72 \\
29 \\
15 \\
42\end{array}$ & 40 \\
\hline H.A. & 30 & 30 & 19.6 & 12.8 & 60 & 17 & \\
\hline M.T.f & 30 & 30 & 13.4 & 8.7 & 10 & 18 & \\
\hline W.J.A. $\ddagger$ & 30 & 30 & 17.9 & 11.8 & 100 & 23 & \\
\hline D.W. & 30 & 30 & 19.2 & 13.2 & 16 & 17 & \\
\hline L.M.f & 30 & 30 & 26.1 & 14.4 & 58 & 22 & \\
\hline
\end{tabular}

* 7.5 per cent solution.

+15 per cent solution.

$\ddagger$ Thyrotoxic patient.

the preparation of whole blood filtrates were employed. The filtrates were then freed of glucose by means of yeast fermentation, by the method of Somogyi. Control tubes of glucose and of yeast suspension were simultaneously incubated with the blood filtrates. After adequate fermentation, the filtrates were centrifuged and filtered. The concentration of galactose was then determined in the filtrate by the method of Benedict, using a KlettSummerson Photoelectric Colorimeter.

\section{Determination of galactose in succus entericus.}

The volume of each sample was measured. To $2 \mathrm{ml}$. of each sample were added $17 \mathrm{ml}$. of $\mathrm{H}_{2} \mathrm{O}, 0.5 \mathrm{ml}$. of 10 per cent $\mathrm{ZnSO}_{4}$, and $0.5 \mathrm{ml}$. of $0.5 \mathrm{~N} \mathrm{NaOH}$. This was shaken and filtered. The excess zinc was removed by adding a pinch of anhydrous $\mathrm{Na}_{2} \mathrm{CO}_{3}$, shaking well and filtering. In most instances the first 2 samples were diluted further, so that the final dilution was 1 to 100 . Two ml. of each of the diluted samples were then analyzed for galactose.

\section{RESULTS AND DISCUSSION}

This method of studying the absorption of sugar from the duodeno-jejunal area was highly satis- factory in that it allowed control of the amount, concentration and time during which the sugar was delivered to a selected area of the intestine. The absorbing or experimental period, furthermore, could be abruptly terminated, an accomplishment not satisfactorily attained by other methods employable in the human subject (Table I).

Galactose, when given in 10 per cent solution, was found to be absorbed at a fairly constant rate in the same subject in repeated tests extending over intervals of 30,60 and 90 minutes (Tables I and II) and varied between 13.4 and 25.6 grams per $1 / 2$ hour for the different subjects. Calculating the grams absorbed on the basis of body surface area per $1 / 2$ hour gave a closer correlation to serve as a basis for comparison in the different individuals (29d). The rates calculated on this basis were found to range from 8.7 to 15.7 grams per square metre of body surface per $1 / 2$ hour, with an average value of 11.2 grams (Tables II and III).

No differences were observed between the rates at which the galactose was absorbed in 6 healthy and in 5 thyrotoxic patients, nor was there any notable difference in the blood galactose concentration of the 2 groups (Tables III and IV).

Furthermore, as can be seen by reference to Table III, there was no direct correlation between the blood galactose concentration and the amount of that sugar absorbed during a $1 / 2$ hour period of its administration. When the administration was continued for a full hour, the second or 1-hour blood specimen, showed a somewhat higher galactose concentration than when the galactose was instilled for only $1 / 2$ hour. The blood galactose concentrations obtained during the longer period of administration tended to resemble those after the oral administration of the sugar (Tables IV and V). This provides experimental proof that a variation in gastric motility, by increasing or decreasing the amount of galactose available for absorption, materially alters its concentration in the blood, even though the ability to absorb the sugar.from the duodeno-jejunal area remains constant.

In view of these observations, serious doubt necessarily arises as to what, if any, value the glactose tolerance test has as a means of arriving at an index of intestinal absorption. Certainly, on the basis of these experiments, it seems valueless. 
TABLE IV

A comparison of the blood galactose concentration after its oral administration, and after its intra-duodenal administration in normal and thyrotoxic individuals

\begin{tabular}{|c|c|c|c|c|c|c|}
\hline \multirow{2}{*}{ Subject } & \multirow{2}{*}{$\begin{array}{l}\text { Galactose } \\
\text { adminis- } \\
\text { tered }\end{array}$} & \multirow{2}{*}{$\begin{array}{l}\text { Method of } \\
\text { adminis- } \\
\text { tration } \\
-\end{array}$} & \multicolumn{3}{|c|}{ Blood galactose concentration } & \multirow{2}{*}{ Remarks } \\
\hline & & & $\begin{array}{c}\text { After } \\
\text { thour }\end{array}$ & $\begin{array}{l}\text { After } \\
1 \text { hour }\end{array}$ & $\underset{2 \text { hours }}{\text { After }}$ & \\
\hline G.C. & $\begin{array}{l}\text { grams } \\
40 \\
30 \\
\end{array}$ & $\begin{array}{l}\text { Oral } \\
\text { Tube }\end{array}$ & $\begin{array}{c}\text { mgm. per cent } \\
38 \\
88\end{array}$ & $\begin{array}{c}\text { mgm. per cent } \\
16 \\
69\end{array}$ & $\begin{array}{c}m g m . \text { per cent } \\
10\end{array}$ & $\begin{array}{l}\text { Control subject. Urinary excretion, } 0.68 \\
\text { gram in } 5 \text { hrs. }\end{array}$ \\
\hline M.B. & $\begin{array}{l}40 \\
60.5 \\
30\end{array}$ & $\begin{array}{l}\text { Oral } \\
\text { Tube } \\
\text { Tube }\end{array}$ & $\begin{array}{l}62 \\
52 \\
58\end{array}$ & $\begin{array}{l}45 \\
66 \\
22\end{array}$ & $\begin{array}{r}24 \\
9\end{array}$ & $\begin{array}{l}\text { Control subject. Urinary excretion, } 1.5 \\
\text { grams in } 5 \mathrm{hrs} \text {. }\end{array}$ \\
\hline C.B. & $\begin{array}{l}0 \\
22.5 \\
60 \\
30 \\
45\end{array}$ & $\begin{array}{l}\text { Oral } \\
\text { Tube } \\
\text { Tube } \\
\text { Tube } \\
\text { Tube }\end{array}$ & $\begin{array}{l}77 \\
42 \\
37 \\
42 \\
55\end{array}$ & $\begin{array}{r}110 \\
15 \\
29 \\
42\end{array}$ & 84 & $\begin{array}{l}\text { Control subject. Urinary excretion, } 1.07 \\
\text { grams in } 5 \mathrm{hrs.} \\
\text { Urinary excretion, } 0.4 \text { gram in } 5 \mathrm{hrs.}\end{array}$ \\
\hline L.D. & 40 & Oral & 39 & 59 & 8 & Control subject \\
\hline L.M. & 30 & Tube & 58 & 22 & & $\begin{array}{l}\text { Thyrotoxic patient. Urinary excretion, } 0.58 \\
\text { gram in } 5 \text { hrs. }\end{array}$ \\
\hline W.J.A. & $\begin{array}{l}40 \\
30\end{array}$ & $\begin{array}{l}\text { Oral } \\
\text { Tube }\end{array}$ & $\begin{array}{r}38 \\
100\end{array}$ & $\begin{array}{l}48 \\
23\end{array}$ & & Thyrotoxic patient \\
\hline D.W. & $\begin{array}{l}40 \\
30\end{array}$ & $\begin{array}{l}\text { Oral } \\
\text { Tube }\end{array}$ & $\begin{array}{l}20 \\
16\end{array}$ & $\begin{array}{l}37 \\
17\end{array}$ & & Thyrotoxic patient \\
\hline
\end{tabular}

When glucose was given $1 / 2$ hour prior to the administration of galactose, no matter whether the 2 sugars were administered orally or intra-duodenally, a considerable lowering of the concentra-

TABLE $\mathbf{V}$

The effects of the previous administration of glucose on the blood galactose concentration in normal subjects

\begin{tabular}{|c|c|c|c|c|c|c|}
\hline \multirow{2}{*}{ Subject } & \multirow{2}{*}{$\begin{array}{l}\text { Galac- } \\
\text { tose } \\
\text { ad- } \\
\text { minis- } \\
\text { tered }\end{array}$} & \multirow{2}{*}{$\begin{array}{l}\text { Method } \\
\text { of ad- } \\
\text { minis- } \\
\text { tration }\end{array}$} & \multirow{2}{*}{$\begin{array}{c}\text { Galactose } \\
\text { absorbed per } \\
\text { sq. meter of } \\
\text { body surface } \\
\text { area per } \\
\text { hour }\end{array}$} & \multicolumn{3}{|c|}{$\begin{array}{l}\text { Blood galactose } \\
\text { concentration }\end{array}$} \\
\hline & & & & t hour & 1 hour & 2 hours \\
\hline G.C. & $\begin{array}{c}\text { grams } \\
40 \\
30 \\
30^{*}\end{array}$ & $\begin{array}{l}\text { Oral } \\
\text { Tube } \\
\text { Tube }\end{array}$ & $\begin{array}{l}12.1 \\
12.0\end{array}$ & $\begin{array}{c}\text { mgm. } \\
\text { per } \\
\text { cent } \\
38 \\
88\end{array}$ & $\begin{array}{c}\text { mgm. } \\
\text { per } \\
\text { cent } \\
16 \\
69 \\
12\end{array}$ & $\begin{array}{c}\underset{\text { per }}{\operatorname{mgm} .} \\
\text { cent } \\
10\end{array}$ \\
\hline M.B. & \begin{tabular}{l|}
40 \\
30 \\
$30 *$
\end{tabular} & $\begin{array}{l}\text { Oral } \\
\text { Tube } \\
\text { Tube }\end{array}$ & $\begin{array}{l}15.5 \\
14.2\end{array}$ & $\begin{array}{l}62 \\
58\end{array}$ & $\begin{array}{l}45 \\
22 \\
17\end{array}$ & 24 \\
\hline C.B. & $\begin{array}{l}40 \\
30^{*} \\
30 \\
30^{*}\end{array}$ & $\begin{array}{l}\text { Oral } \\
\text { Oral } \\
\text { Tube } \\
\text { Tube }\end{array}$ & $\begin{array}{l}13.2 \\
12.2\end{array}$ & $\begin{array}{r}77 \\
2 \\
42\end{array}$ & $\begin{array}{r}110 \\
17 \\
29 \\
16\end{array}$ & $\begin{array}{l}84 \\
13\end{array}$ \\
\hline
\end{tabular}

* In this instance 30 grams of glucose were administered 1 hour before the galactose and by the same route. tion of the galactose in the blood occurred (Table V). This effect was not due to any decrease in the amount of galactose absorbed, thus indicating that the lowered blood concentration resulted from some other influence exerted by the glucose. These observations confirm those previously made, chiefly on experimental animals, which indicate that the metabolism of galactose depends in some way on the availability of glucose $(20,25)$.

The values obtained by us for the concentration of galactose in the blood of normal subjects were higher than those reported by Althausen (5), but they were of the same order of magnitude as have been reported by other observers $(28,29 a, 30)$.

\section{CONCLUSIONS}

1. Employing the technique of Nicholson and Chornock in a study of the absorption of a 10 per cent solution of galactose from the upper human intestine, administered at a rate of $10 \mathrm{ml}$. per minute, the rate was found to range from 8.8 to 15.7 grams per square meter of body surface area per $1 / 2$ hour, with an average of 11.2 grams. 
2. The thyrotoxic patient, under identical conditions, does not absorb galactose any faster than the healthy individual.

3. The degree of galactemia bears no constant relation to the amount of galactose absorbed from the intestine in either the normal subject or the thyrotoxic patient.

4. Galactemia may be depressed by the previous administration of glucose without any decrease in the absorption of the galactose. This tends to provide further evidence to Folin's, Berglund's (20) and Bodansky's (25) statements that the retention and utilization of galactose by the body depend to a large extent on the availability of glucose and are not due to any decrease in absorption of the galactose as was thought to be the explanation in animal experiments $(11,12)$.

\section{BIBLIOGRAPHY}

1. Althausen, T. L., A test for intestinal absorption. Am. J. Digest. Dis. \& Nutrition, 1939, 6, 544.

2. Althausen, T. L., The disturbance of carbohydrate metabolism in hyperthyroidism. J. A. M. A., 1940, 115, 101.

3. Althausen, T. L., and Stockholm, M., Influence of the thyroid gland on absorption in the digestive tract. Am. J. Physiol., 1938, 123, 577.

4. Althausen, T. L., and Wever, G. K., Galactose tolerance in hyperthyroidism. J. Clin. Invest., 1937, 16, 257.

5. Althausen, T. L., Lockhart, J. C., and Soley, M. H., A new diagnostic test (galactose) for thyroid disease. Am. J. M. Sc., 1940, 199, 342.

6. Abbott, W. O., Karr, W. G., Glenn, P. M., and Warren, R., The absorption of glucose from the duodenum. Am. J. M. Sc., 1940, 200, 532.

7. Karr, W. G., Abbott, W. O., Hoffman, O. D., and Miller, T. G., The concentration and movement of glucose solutions in the stomach and duodenum. Am. J. M. Sc., 1940, 200, 524.

8. Verzar, F., and McDougall, E. J., Absorption from the Intestine. Longmans, Green and Co. Ltd., London, England, 1936.

9. Warren, R., Karr, W. G., Hoffman, O., and Abbott, W. O., The absorption and expulsion of glucose from the stomach. Am. J. M. Sc., 1940, 200, 639.

10. Morrison, J. L., Shay, H., Ravdin, I. S., and Cahoon, R., Absorption of glucose from the stomach of the dog. Proc. Soc. Exper. Biol. and Med., 1939, 41, 131.

11. Cori, C. F., The influence of insulin on the utilization of glucose, fructose, and dihydroxyacetone. J. Biol. Chem., 1928, 76, 755.

12. Cori, C. F., The fate of sugar in the animal body. J. Biol. Chem., 1925, 66, 691.
13. Groen, J., The absorption of hexoses from the upper part of the small intestine in man. J. Clin. Invest., 1937, 16, 245.

14. Bollman, J. L., Mann, F. C., and Power, M. H., The utilization of galactose following complete removal of the liver. Am. J. Physiol., 1935, 111, 483.

15. Duel, H. J., Jr., Intermediary metabolism of fructose and galactose. Physiol. Rev., 1936, 16, 173.

16. Banks, B., Sprague, P., and Snell, A., Clinical evaluation of the galactose tolerance test. J. A. M. A., 1933, 100, 1987.

17. Bassett, A. M., Althausen, T. L., and Coltrin, G., A new intravenous galactose clearance test for differentiation of obstructive from parenchymatous jaundice. Proc. Soc. Exper. Biol. and Med., 1940, 45, 405.

18. Bloch, J., and Weisz, M., Reflex-oder Resorptionshyperglykamie. Ztschr. f. d. ges. Exp. Med., 1930, 69, 453.

19a. Budak, M., Testing of liver function by means of intravenous galactose solution. Chem. Abstracts, 1933, 27, 3732.

19b. Cori, C. F., and Cori, G. T., The carbohydrate metabolism of adrenalectomized mice and rats. J. Biol. Chem., 1927, 74, 473.

20. Folin, O., and Berglund, H., Some new observations and interpretations with reference to transportation, retention and excretion of carbohydrates. J. Biol. Chem., 1922, 51, 213.

21. Harding, V. J., and Van Nostrand, F. H., Variations in blood and urinary sugar after ingestion of galactose. J. Biol. Chem., 1930, 85, 765.

22. Jankelson, I. R., and Lerner, H. H., Intravenous galactose liver function test. Am. J. Digest. Dis. and Nutrition, 1934, 1, 310.

23. Pollack, S., Beitrag zur Leberfunktionsprufung mittels intravenoser Kalaktoselosung. Wien. Arch. F. inn. Med., 1932, 22, 317.

24. Tumen, H. J., and Piersol, G. M., The value of alimentary galactosuria in the diagnosis of jaundice. Ann. Int. Med., 1933, 7, 311.

25. Bodansky, M., Fructose, glucose and galactose tolerance in dogs. J. Biol. Chem., 1923, 56, 387.

26. Nicholson, J. T. L., and Chornock, F. W., Intubation studies of the human small intestine. XXII. An improved technique for the study of absorption; its application to ascorbic acid. J. Clin. Invest., 1942, 21, 505.

27. Miller, T. G., and Abbott, W. O., Intestinal intubation: a practical technique. Am. J. M. Sc., 1934, 187, 595.

28. Harding, V. J., and Grant, G. A., Metabolism of galactose. J. Biol. Chem., 1933, 99, 629.

29a. MacLaglan, N. F., and Rundle, F. F., Liver function in thyrotoxicosis. Quart. J. Med., 1940, 215, July.

29b. May, C. D., and McCreary, J. F., The glucose tolerance test in celiac disease. J. Ped., 1940, 17, 1943. 
29c. Marrazzi, R., The influence of adrenalectomy and of fasting on the intestinal absorption of carbohydrates. Am. J. Physiol., 1940, 131, 36.

29d. McKay, E. M., and Bergman, H. C., The rate of absorption of glucose from the intestinal tract. J. Biol. Chem., 1933, 101, 453.

29e. Meczner, L., A combined liver and kidney functional test by means of the galactose test. Chem. Abstracts, 1933, 27, 3733.

30. Roe, J. H., and Schwartzman, A. S., Galactose tolerance in normal and diabetic subjects and the effect of insulin upon galactose metabolism. J. Biol. Chem., 1932, 96, 717.
31. Pierce, H. B., The absorption and utilization of carbohydrates. J. Nutrition, 1935, 10, 689.

32. Ravdin, I. S., Johnston, C. G., and Morrison, P. J., Comparison of concentrations of glucose in stomach and intestine after intragastric administration. Proc. Soc. Exper. Biol. and Med., 1933, 30, 955.

35. Rowe, A. W., The metabolism of galactose; III. The influence of disturbed endocrine function. Am. J. M. Sc., 1935, 190, 686.

36. Shay, H., Gershon-Cohen, J., Fels, S. S., and Monroe, F. L., The absorption and dilution of glucose solutions in the human stomach and duodenum. Am. J. Digest. Dis. \& Nutrition, 1939, 6, 535. 